\title{
High crop yield losses induced by potential HONO sources - - a case study in the North China Plain
}

\section{Jingwei Zhang}

nstitute of Atmospheric Physics (IAP), Chinese Academy of Sciences

\section{Haiyan Ran}

Institute of Atmospheric Physics (IAP), Chinese Academy of Sciences

\section{Yitian Guo}

Institute of Atmospheric Physics (IAP), Chinese Academy of Sciences

Chaoyang Xue

CNRS-LPC2E https://orcid.org/0000-0001-6673-7716

Xingang Liu

Beijing Normal University

\section{Yu Qu}

Institute of Atmospheric Physics (IAP), Chinese Academy of Sciences

\section{Yele Sun}

Institute of Atmospheric Physics (IAP), Chinese Academy of Sciences

\section{Qiang Zhang}

Tsinghua University https://orcid.org/0000-0002-8376-131X

\section{Yujing Mu}

Research Center for Eco-Environmental Sciences, Chinese Academy of Sciences

\section{Yong Chen}

Institute of Atmospheric Physics (IAP), Chinese Academy of Sciences

\section{Jing Wang}

China Agricultural University https://orcid.org/0000-0002-7960-0396

Junling An ( $\nabla$ anjl@mail.iap.ac.cn )

institute of atmospheric physics, Chinses Academy of Sciences

\section{Article}

Keywords:

Posted Date: February 8th, 2021

DOI: https://doi.org/10.21203/rs.3.rs-210489/v1 
License: (c) (i) This work is licensed under a Creative Commons Attribution 4.0 International License. Read Full License 
1 High crop yield losses induced by potential HONO sources

2 a case study in the North China Plain

4 Nitrous acid (HONO) is a major source of hydroxyl radicals in the troposphere through

5 its photolysis, and can significantly influence ozone $\left(\mathrm{O}_{3}\right)$ levels, thereby causing

6 considerable crop yield losses. Previous studies have assessed relative crop yield

7 losses by using exposure-response equations with observed or simulated $\mathrm{O}_{3}$, however,

8 the contribution of enhanced $\mathrm{O}_{3}$ due to potential HONO sources to the crop yield

9 losses has never been quantified. In this study, for the first time, we evaluated the crop

10 yield losses caused by potential HONO sources in the North China Plain (NCP), which

11 is one of the major grain-producing areas in China suffering from heavy $\mathrm{O}_{3}$ pollution,

12 by using the Weather Research and Forecasting/Chemistry (WRF-Chem) model during

13 the wheat and maize growing seasons of 2016. HONO simulations were significantly

14 improved after including six potential HONO sources. The potential HONO sources

15 produced a daily maximum 8-h $\mathrm{O}_{3}$ enhancement of 8.1/8.2 ppb during the wheat/maize

16 growing seasons, respectively, and led to $\sim 11.4 \% / 3.3 \%$ relative yield losses for

17 wheat/maize, respectively, corresponding to approximately US $\$ 3.78 / 0.66$ billion losses,

18 respectively, in NCP in 2016. Potential HONO sources play a significant role in $\mathrm{O}_{3}$

19 formation and may induce high crop yield losses globally. 
itrous acid (HONO) is an important source of hydroxyl radicals $(\mathrm{OH})$ in the troposphere, and contributes $20-80 \%$ of the primary $\mathrm{OH}$ production ${ }^{1-3}$ (Table S1) through its photolysis (R1) during the daytime:

$$
\mathrm{HONO}+h v(<400 \mathrm{~nm}) \rightarrow \mathrm{NO}+\mathrm{OH}
$$

However, the sources of HONO are hitherto not well understood, and the current air quality models always severely underestimate ground HONO observations by using a default chemical mechanism ${ }^{4-8}$, which only considers the dominant gas-phase production of HONO, i.e., the reverse reaction of R1. To improve HONO simulations, some potential HONO sources (e.g., traffic emissions, soil emissions, inorganic nitrate photolysis, and $\mathrm{NO}_{2}$ heterogeneous reactions on ground/aerosol surfaces) have been coupled into several air quality models ${ }^{4-9}$. These HONO improvements produce more $\mathrm{OH}$, which is favorable for ozone $\left(\mathrm{O}_{3}\right)$ formation in areas with high emissions of nitrogen oxides $\left(\mathrm{NO}_{\mathrm{x}}\right)$ and volatile organic compounds (VOCs) (R2-R8).

$$
\mathrm{OH}+\mathrm{CO} \rightarrow \mathrm{H}+\mathrm{CO}_{2}
$$

$$
\mathrm{H}+\mathrm{O}_{2} \rightarrow \mathrm{HO}_{2}
$$

$$
\mathrm{OH}+\mathrm{VOCs} \rightarrow \mathrm{RO}_{2}
$$

$$
\mathrm{HO}_{2}+\mathrm{NO} \rightarrow \mathrm{NO}_{2}+\mathrm{OH}
$$

$$
R \mathrm{O}_{2}+\mathrm{NO} \rightarrow \beta \cdot \mathrm{NO}_{2}+\mathrm{RO}, \beta<1
$$

$$
\mathrm{NO}_{2}+h v \rightarrow \mathrm{O}+\mathrm{NO}
$$

$$
\mathrm{O}+\mathrm{O}_{2} \rightarrow \mathrm{O}_{3}
$$


$\mathrm{O}_{3}$ in the atmosphere can affect plants mainly through stomatal-induced biochemical reactions, producing reactive oxygen species, which could react with plant cell structure, and cause damage at molecular, biochemical and physiological levels, and eventually lead to a decline in plant productivity 10-12. Atmospheric modelling studies in recent years have evaluated the impact of some potential HONO sources on $\mathrm{O}_{3}$ formation, and have shown that hourly $\mathrm{O}_{3}$ enhancements due to the considered yield, however, has not been quantified by current studies. potential HONO sources ranging from several to tens of ppb worldwide ${ }^{4-9}$ (Table. S2). The enhanced $\mathrm{O}_{3}$ caused by the considered potential $\mathrm{HONO}$ sources may further damage plants and reduce the crop

To understand the relationship between $\mathrm{O}_{3}$ exposure and crop yield losses, some open-top chamber experiments and ozone-free air-controlled enrichment experiments have been conducted globally over the past decades ${ }^{13,14}$. Based on these field experiments, a series of cumulative metrics and exposureresponse (ER) equations have been proposed ${ }^{13-18}$ and widely applied to evaluate the yield losses worldwide. For instance, Avnery et al. ${ }^{19}$ estimated the reduction in the global wheat and maize harvest induced by $\mathrm{O}_{3}$ and found that the relative yield losses in 2030 could reach $6.9-36 \%$ and $6.5-11.9 \%$, respectively, compared with the yields in 2000. Feng et al. ${ }^{20}$ found an increasing trend of maize yield losses in the North China Plain (NCP) from 8.2\% (2014) to $13.4 \%$ (2017). Zhao et al. ${ }^{21}$ estimated the effects of surface $\mathrm{O}_{3}$ on crops across China during 2015-2018 and found increasing trends in wheat and maize yield reductions. The national yield reduction rate of winter wheat increased from $20.1 \%$ (2015) to $33.3 \%$ (2018), much larger than that of maize (from 5.0\% (2015) to $6.3 \%$ (2018)), and the largest losses of both crops occurred in $\mathrm{NCP}^{21}$.

$\mathrm{NCP}$ is one of the major crop-producing areas in China, producing $\sim 70 \%$ of the total wheat yield and $\sim 25 \%$ of the total maize yield in China in 2016 (Table S3). However, this region has high 
anthropogenic emissions of $\mathrm{NO}_{\mathrm{x}}$ and VOCs and has suffered from elevated mixing ratios of $\mathrm{O}_{3}{ }^{22,23}$, which would further reduce the crop yields in the future. To our knowledge, the current studies evaluated total crop yield losses by using observed or simulated $\mathrm{O}_{3}$ mixing ratios and the ER equations, however, the effect of potential HONO sources on crop yield losses has never been assessed despite the important role of $\mathrm{HONO}$ in $\mathrm{O}_{3}$ formation. In this study, we made the first attempt to quantify the crop yield losses caused by potential HONO sources for the wheat-maize rotation system in NCP in 2016 by using the updated Weather Research and Forecasting/Chemistry (WRF-Chem) model.

\section{Results}

\section{Comparison between simulated and observed $\mathrm{HONO} / \mathrm{O}_{3}$}

The hourly-averaged observed HONO at the rural/urban sites was $0.43 / 0.63 \mathrm{ppb}$, and was significantly underestimated by the model base case $(0.01 / 0.02 \mathrm{ppb})$. However, model performance was significantly improved after inserting the six potential HONO sources (case 6S) (Fig. 1a\&b) and the modeled average HONO was $0.60 / 0.55 \mathrm{ppb}$ at the rural/urban sites. The values of NMB, RMSE and IOA were also significantly improved (Table S4) in case 6S compared with the base case. For the mean diurnal patterns of HONO at the two sites (Fig. 1c\&d), the base case always severely underestimated the observations, and the largest values of HONO occurred around noontime due to high mixing ratios of $\mathrm{OH}$ favoring the homogeneous formation of $\mathrm{HONO}(\mathrm{NO}+\mathrm{OH} \rightarrow \mathrm{HONO})($ Fig. 1c\&d) but were merely tens of ppt (Table S5). After considering the six potential HONO sources, the diurnal patterns of $\mathrm{HONO}$ for case $6 \mathrm{~S}$ were significantly improved for both periods, HONO accumulated during nighttime and was photolyzed in daytime, being consistent with the observations (Fig. 1c\&d). The relative contribution of each potential HONO source to the surface HONO mixing 
ratio is shown in Fig. S1. The $\mathrm{NO}_{2}$ heterogeneous reaction on the ground surface dominated nighttime and daytime HONO formation. Additionally, nitrate photolysis contributed $\sim 5-20 \%$ of the daytime HONO; soil emissions could be neglected at 69 NCP sites during the daytime and in urban Beijing during the whole day, but could contribute $\sim 20-30 \%$ at the rural site during nighttime; traffic emissions were small during daytime and contributed $\sim 10 \%$ in nighttime; indoor emissions were close to the traffic emissions at the urban site $(10-15 \%)$ but could be neglected in the rural areas $(<1 \%)$; and the $\mathrm{NO}_{2}$ heterogeneous reaction on aerosol surfaces was minor during daytime and contributed $\sim 5 \%$ during nighttime. The daytime underestimation $(\sim 0.1-0.2 \mathrm{ppb})$ of HONO for case $6 \mathrm{~S}$ may represent unknown sources of HONO.

The 69-site-averaged hourly $\mathrm{O}_{3}$ simulations were significantly improved for the $6 \mathrm{~S}$ case compared with the base case overall (Fig. S2). The averaged $\mathrm{O}_{3}$ diurnal variations during the wheat and maize growing seasons are presented in Fig. 1e\&f and Table S6. Clearly, the potential HONO sources significantly enhanced daytime $\mathrm{O}_{3}$ and narrowed the model underestimation (Fig. 1e\&f) due to more $\mathrm{OH}$ and $\mathrm{HO}_{2}$ production caused by the improved HONO (Fig. S3\&S4). The daily maximum 8-h (10:00-17:59) (DMA8) $\mathrm{O}_{3}$ was 45.9 (base case), 53.8 (6S case) and 57.4 (Obs) ppb during the wheat growing season (Table S6), whereas it was 56.7 (base case), 65.6 (6S case) and 64.5 (Obs) ppb during the maize growing season (Table S6). During the two growing seasons (Fig. S5), we found a significant enhancement in the net $\mathrm{O}_{3}$ production rate in case $6 \mathrm{~S}$ after considering the six potential HONO sources (Fig. S5), and the enhanced $\mathrm{O}_{3}$ caused by the potential HONO sources could further damage plants and cause crop yields reduction. 

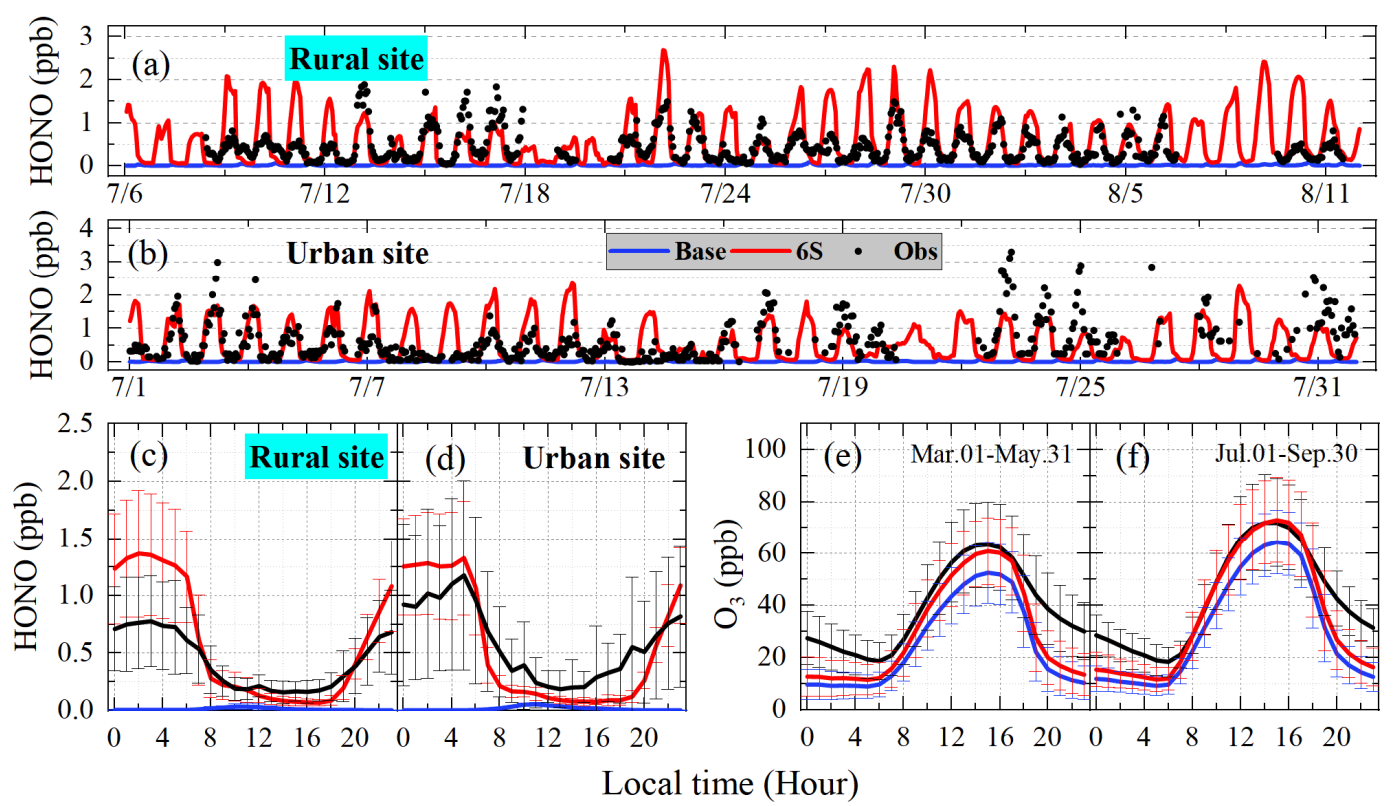

104 Fig. 1 | Comparison of simulated (Base and 6S cases) and observed hourly and diurnal HONO mixing ratios at 105 the rural (a\&c) and urban (b\&d) sites in summer of 2016, and comparison of simulated (Base and 6S cases) and observed 69-site-averaged diurnal $\mathrm{O}_{3}$ in the North China Plain during the wheat (e) and maize (f) growing seasons in 2016.

\section{O3 distributions and enhancements due to improved HONO}

The spatial patterns and enhancements of $\mathrm{O}_{3}$ in NCP are shown in Fig. 2. During the wheat growing season, the DMA8 $\mathrm{O}_{3}$ for the base case was $40-55$ ppb in most areas of NCP (Fig. 2(a1)), while that for the 6S case was 50-65 ppb, decreasing gradually from south to north (Fig. 2(b1)), and the corresponding enhancement (Fig. 2(c1)) also showed a descending trend from south $(\sim 10-12 \mathrm{ppb})$ to north ( $\sim 5 \mathrm{ppb})$. The regional-averaged $\mathrm{DMA}_{8} \mathrm{O}_{3}$ enhancement was $8.1 \mathrm{ppb}$ (exclusive of $\mathrm{O}_{3}$ over the ocean) (Fig. S6), in case 6S compared to the base case. During the maize growing season, the simulated DMA8 $\mathrm{O}_{3}$ mean was $\sim 40-65 \mathrm{ppb}$ for the base case (Fig. 2(a2)) and $\sim 50-75$ ppb for the 6S case (Fig. 2(b2)) from July to September, being larger than that in spring due to higher temperature and stronger solar radiation. The spatial patterns showed a decreasing trend from west to the east for both cases, 
and the enhancement also gradually decreased from west $(\sim 12-15 \mathrm{ppb})$ to the east $(\sim 5-8 \mathrm{ppb})$ (Fig. 2(c2)) with a mean value of $8.2 \mathrm{ppb}$ excluding the ocean (Fig. S6). Considering the positive relationship between $\mathrm{O}_{3}$ mixing ratios and crop RYLs, a higher RYL induced by the potential HONO sources would probably occur in southern NCP for wheat, and in western NCP for maize.
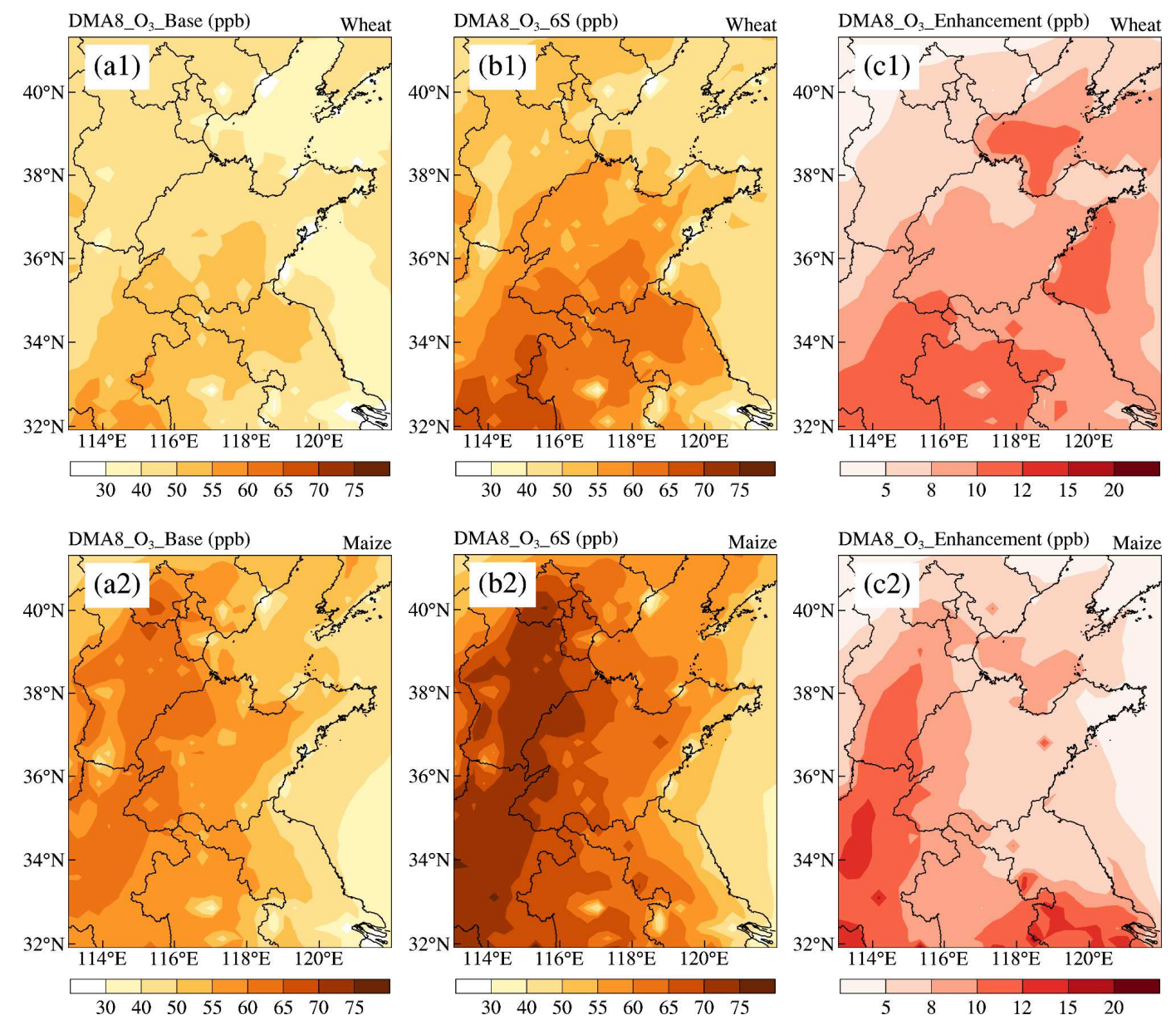

Fig. 2 | Daily maximum 8-h (10:00-17:59) surface $\mathrm{O}_{3}$ simulations for the base (a1/a2) and 6S cases (b1/b2) and the enhancements (c1/c2) induced by the potential HONO sources during the wheat/maize growing season.

\section{RYL caused by the potential HONO sources in NCP}

Based on the hourly simulated $\mathrm{O}_{3}$, the 14 ER equations (Table 1) for the base and 6S cases were used, 
in Fig. 3 and Table S7. For wheat, large RYL variations can be found between those equations. The largest RYL mean was 0.207 as calculated by equation SUM06_1, whereas the smallest RYL mean was 0.030 as calculated by equation M7_1; the RYL mean calculated by the nine equations was 0.114 , while the median mean was 0.108 . For maize, the overall RYL was much smaller than that for wheat because of its higher resistance to $\mathrm{O}_{3}$ exposure; the largest RYL mean was 0.058 (AOT40_6), and the smallest RYL mean was 0.012 (M7_2); the RYL mean calculated by the five equations was 0.033 , while the median mean was 0.032 . Considering the large variations of RYL among different equations and the complex crop response to $\mathrm{O}_{3}$ exposure among diverse cultivars ${ }^{24}$, the mean RYL value for wheat $(0.114)$ and maize $(0.033)$ could be more representative than that of a single equation, thus, we can derive that HONO induced $\sim 11.4 \%$ and $\sim 3.3 \%$ of RYL for wheat and maize, respectively, in NCP in 2016.

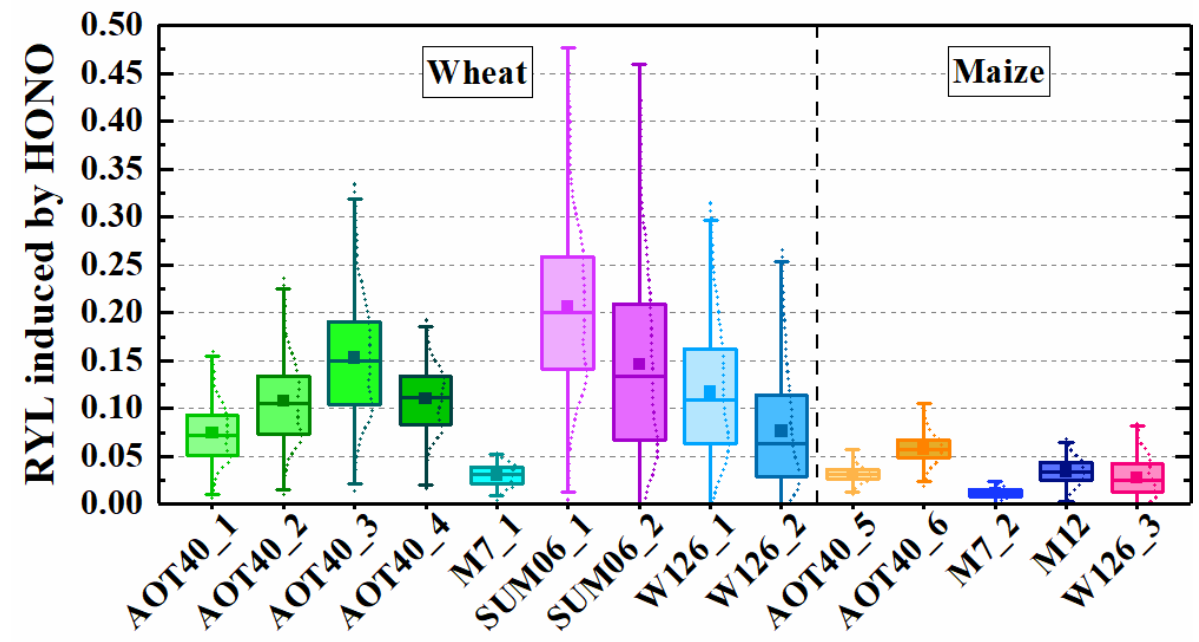

Fig. 3 Box plots of the relative yield loss (RYL) induced by the potential HONO sources calculated by the 14 exposure-response (ER) equations in NCP in 2016.

The spatial patterns computed by the nine RY equations for wheat are shown in Fig. S7. The RY 145 for the base case decreased from north to south for all the equations; after considering the potential 
HONO sources, a noticeable reduction of RY can be seen in southern NCP (Fig.S7). The spatial variation of RYL also showed that higher losses occurred in southern NCP, and relatively lower losses occurred in northern NCP (Fig. S7), corresponding to the DMA8 $\mathrm{O}_{3}$ spatial patterns and enhancements during the growing season (Fig. 2(a1-c1)). The spatial patterns computed by the five RY equations for maize are given in Fig. S8. Maize was relatively insensitive to $\mathrm{O}_{3}$ exposure compared with wheat.

Smaller RY values occurred in western NCP for both cases (Fig. S8) with higher DMA8 $\mathrm{O}_{3}$ (Fig. 2(a2b2)), and larger RYL values also occurred in western $\mathrm{NCP}$ (Fig. S8) with higher $\mathrm{O}_{3}$ enhancements (Fig. 2(c2)). and observed $\mathrm{O}_{3}$ (RYLobs) were calculated (E8-E10) for each of the fourteen ER equations (Fig.

For the $69 \mathrm{O}_{3}$ observational sites, the mean RYL values of the base $\left(\mathrm{RYL}_{\text {base }}\right)$ and $6 \mathrm{~S}\left(\mathrm{RYL}_{6 \mathrm{~S}}\right)$ cases 4a\&b). Among these results, $\mathrm{RYL}_{\text {base }}$ showed the smallest value due to the lowest $\mathrm{O}_{3}$ mixing ratio, RYL 6 S was in the middle and the difference between $\mathrm{RYL}_{6 \mathrm{~S}}$ and $\mathrm{RYL}_{\text {base }}$ represented the RYL caused by the enhanced $\mathrm{O}_{3}$ induced by the potential HONO sources, while $\mathrm{RYL}_{\text {obs }}$ showed the largest value and represented the actual RYL calculated by using the observed $\mathrm{O}_{3}$, which is comparable with the RYL reported by Feng et al. ${ }^{20}$ and Zhao et al. ${ }^{21}$ in the same region in 2016 . The calculated relative contribution is shown in the lower panel of Fig. 4. Although the RYL showed a large variation when using different equations (Fig. 4a\&b), the relative contribution for each of the equations used remained relatively stable (Fig. 4c\&d), especially for wheat, ranging from 27.32\% (AOT40_4) to 42.71\% (W126_2), with a mean of 32.67\% (Fig. 4c). The relative contribution for maize ranged from 34.34\% (M12) to 75.33\% (W126_3), with a mean of 39.56\% (excluding W126_3 with small RYL values and large standard deviation (SD)) (Fig. 4d). From the above analysis, we can conclude that the enhanced $\mathrm{O}_{3}$ caused by the potential HONO sources contributed $\sim 30 \%$ of the actual RYL for wheat, and $\sim 40 \%$ 


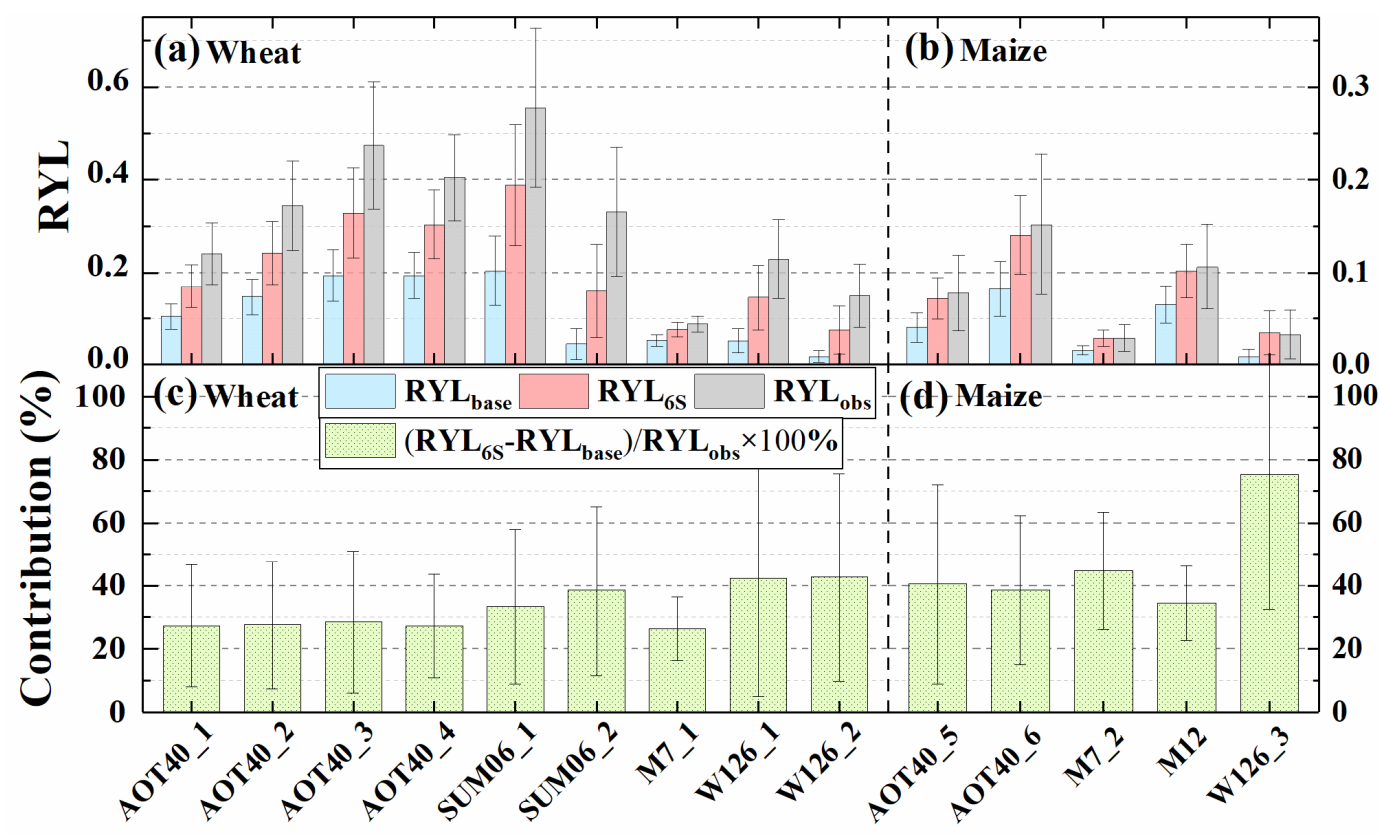

Fig. 4 | The 69-site-averaged relative yield loss (RYL) values calculated by using 14 Exposure-Response (ER) equations for the base (RYL base, light blue histogram) and 6S (RYL 6 , light red histogram) cases and observed $\mathrm{O}_{3}\left(\mathrm{RYL}_{\mathrm{obs}}\right.$, gray histogram) for wheat (a) and maize (b); and the relative contribution of the RYL caused by the enhanced $\mathrm{O}_{3}\left(\mathrm{O}_{3}\right.$ simulations of the $6 \mathrm{~S}$ case minus those of the base case) to the actual RYL ( $\left.\mathrm{RYL}_{\mathrm{obs}}\right)$ for wheat (c) and maize (d).

177 The uncertainties of $\gamma$ and $f$ in the surface HONO simulations were assessed and the corresponding results are given in Fig. S9. The values of $\gamma$ and $f$ were $2.00 \times 10^{-5}, 2.75 \times 10^{-5}$, and $5.00 \times 10^{-5}$ and 0.40 , 1790.55 , and 1.00 for $\alpha=300,200$, and 100, respectively, when the noontime SR reached $900 \mathrm{~W} \mathrm{~m}$. Changes in $\alpha$ values led to slight variations in the HONO simulations but did not change the dominant daytime HONO pattern. 
183 A $\mathrm{J}_{\text {nitrate }} / \mathrm{J}_{\mathrm{HNO} 3}$ ratio of 1 showed a minor HONO increment of only $1-5 \mathrm{ppt}$, and a ratio of 7 merely 184 increased HONO by $\sim 10-20$ ppt after sunrise and could be neglected after noontime; when the ratio 185 increased to 30 , HONO enhancements reached $\sim 20-40$ ppt after sunrise and $\sim 10-20$ ppt in the afternoon; and a ratio of 120 led to a HONO enhancement of $\sim 0.1 \mathrm{ppb}$ after sunrise and $\sim 0.05 \mathrm{ppb}$ in the afternoon. The true value of nitrate photolysis frequency in the atmosphere is still open to debate ${ }^{25-27}$, and we chose a conservative value of 30 for the $6 \mathrm{~S}$ case simulation in this study. Besides, we used a relatively low soil HONO emissions in this study. As reported by Xue et al. ${ }^{28}$, soil HONO emissions could be remarkably enhanced by agricultural nitrogen fertilization, which was not considered in this study because field HONO emission flux measurement is still unavailable.

The DMA8 $\mathrm{O}_{3}$ simulations during the wheat growing season $(53.8 \mathrm{ppb})$ for case $6 \mathrm{~S}$ still underestimated the observations $(57.4 \mathrm{ppb})$ by $3.6 \mathrm{ppb}$ after considering the potential HONO sources. To better improve the $\mathrm{O}_{3}$ simulations, we increased VOC emissions by $15 \%$ or decreased $\mathrm{NO}_{x}$ emissions by $15 \%$ for the whole region during the wheat growing season, and the results are presented emissions or decreasing $\mathrm{NO}_{x}$ emissions, $\mathrm{DMA} 8 \mathrm{O}_{3}$ enhancements among the three emissions scenarios 199 (6S minus Base, 6S_115VOCs minus Base_115VOCs and 6S_85NOx minus Base_85NOx) were minor $(<0.3 \mathrm{ppb})$, suggesting that the RYL differences induced by the potential HONO sources based on the different VOCs or $\mathrm{NO}_{\mathrm{x}}$ emission scenarios were small (Fig. S12).

\section{Discussion}


This study, for the first time, evaluated the crop yield loss induced by the potential HONO sources on a regional scale, and helped to better understand the crop yield losses caused by $\mathrm{O}_{3}$ pollution regionally and globally. Very limited HONO observations suggest that more field observations of HONO in rural and remote areas are urgently needed to further understand the formation mechanisms of HONO and its impacts on the atmospheric environment and crop yields. HONO mixing ratios were positively correlated with $\mathrm{NO}_{x}$ concentrations ${ }^{29}$, however, highly non-linear relationship existed between $\mathrm{O}_{3}$ and VOCs/ $\mathrm{NO}_{\mathrm{x}}$ mixing ratios (Fig. 5). Higher $\mathrm{NO}_{\mathrm{x}}$ mixing ratios can elevate $\mathrm{HONO}$ mixing ratios, which can promote $\mathrm{O}_{3}$ formation, yet higher $\mathrm{NO}_{x}$ mixing ratios would also terminate radicals cycling or titrate with $\mathrm{O}_{3}$ directly, result in $\mathrm{O}_{3}$ decreasing when VOCs are insufficient ${ }^{30}$.

The commercial losses of wheat and maize were estimated according to RYL and the total crop yields obtained from the National Bureau of Statistics of China. The wheat and maize yields in NCP 214 (a rough estimation by using the sum of Anhui, Henan, Jiangsu, Shandong, Hebei, Beijing and Tianjin) 215 in 2016 reached $9.82 \times 10^{7}$ and $6.42 \times 10^{7}$ tons (Table S3), respectively, and the corresponding losses 216 reached $1.26 \times 10^{7}$ (mean wheat RYL of $11.4 \%$ ) and $2.19 \times 10^{6}$ (mean maize RYL of $3.3 \%$ ) tons, respectively, due to the potential HONO sources. The purchase price was $\sim$ US $\$ 0.3 \mathrm{~kg}^{-1}$ for wheat and maize in 2016, and the commercial losses reached $\sim$ US $\$ 3.78$ billion for wheat and $\sim$ US $\$ 0.66$ billion for maize, i.e., a crop loss of $\sim$ US $\$ 4.44$ billion was induced by the potential HONO sources in NCP in 2016 (Fig. 5). 


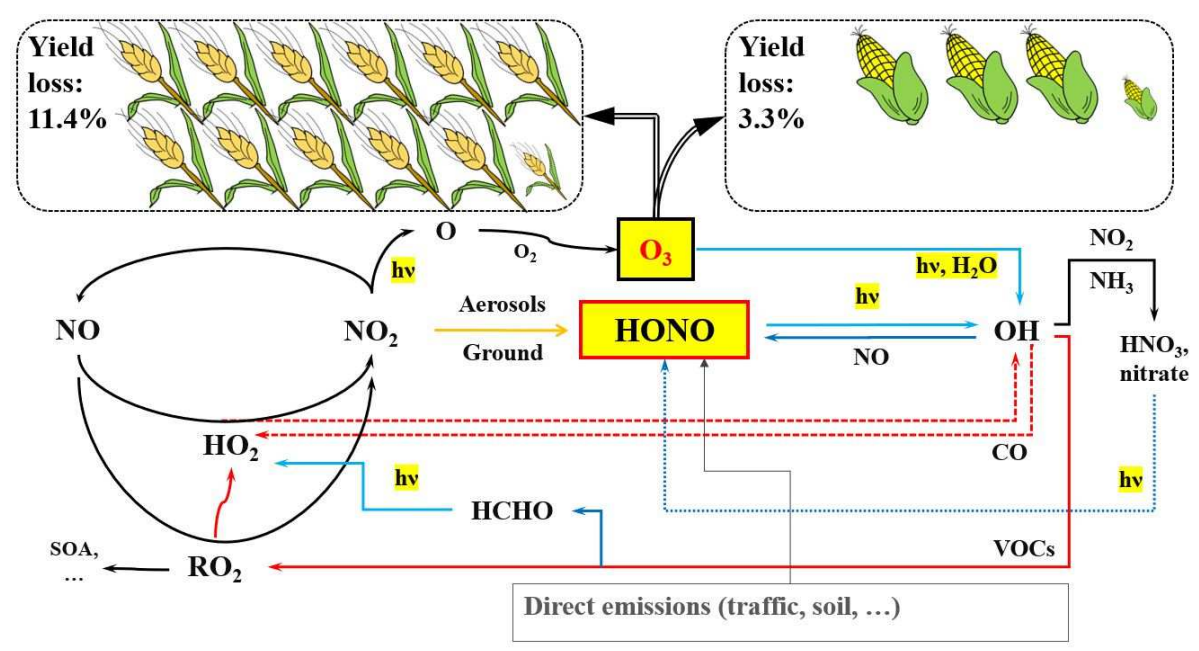

222 Fig. $5 \mid$ The key mechanism of ozone $\left(\mathrm{O}_{3}\right)$ formation induced by nitrous acid (HONO) and the relative yield 223 losses induced by potential HONO sources in North China Plain in 2016 for wheat and maize.

The enhancement of $\mathrm{O}_{3}$ induced by the six potential HONO sources was found in this study and many other regions (Table S2), implying that considerable crop yield losses induced by potential HONO sources may occur globally, and more efforts are needed to better understand HONO sources and their impacts.

\section{Methods}

\section{Crop yield loss evaluation methods}

231 Five cumulative metrics for total ozone exposure (AOT40, M7, M12, SUM06 and W126) were used 232 in this work, and they are defined as follows:

$$
\boldsymbol{A O T 4 0}(\boldsymbol{p p m} \cdot \boldsymbol{h})=\sum_{i=1}^{n}\left(\left[C_{O 3}\right]_{i}-0.04\right) \quad C_{03} \geq 0.04 \mathrm{ppm}
$$

$$
\boldsymbol{M 7}(\boldsymbol{p p} \boldsymbol{b})=\frac{1}{n} \sum_{i=1}^{n}\left[C_{O 3}\right]_{i} \quad \text { i is from 9: } 00 \text { to 15:59 }
$$

$$
\boldsymbol{M 1 2}(\boldsymbol{p p} \boldsymbol{b})=\frac{1}{n} \sum_{i=1}^{n}\left[C_{03}\right]_{i} \quad i \text { is from 8:00 to 19:59 }
$$


238 AOT40 is the sum of differences between hourly $\mathrm{O}_{3}$ mixing ratios and $40 \mathrm{ppb}$ when $\mathrm{O}_{3}$ mixing ratios

$239\left(C_{O 3}\right)$ are $>40 \mathrm{ppb}$ during the crop growing season ${ }^{18}$; M7 and M12 are the $7 \mathrm{~h}$ - and $12 \mathrm{~h}$-averaged 240 daytime surface $\mathrm{O}_{3}$ during the crop growing season ${ }^{17}$; SUM06 emphasizes both exposure duration and 241 peak $\mathrm{O}_{3}{ }^{31}$, and $\mathrm{W} 126$ provides smaller weight factors to lower $\mathrm{O}_{3}$ mixing ratios and larger weight 242 factors to higher $\mathrm{O}_{3}$ mixing ratios based on a weighting function ${ }^{15}$. In this study, the reported ER 243 functions were collected with different $\mathrm{O}_{3}$ exposure metrics, and these functions were independently 244 derived and can be adopted to evaluate the ranges and uncertainties of the relative yield (RY) and relative yield loss (RYL). In total, nine ER functions for wheat and five ER functions for maize (Table 1) were applied with the five metrics described above.

Table. 1 Exposure-Response (ER) equations used to calculate the relative yield (RY) for wheat 249 and maize.

\begin{tabular}{|c|c|c|c|c|c|}
\hline Wheat & Abbrev & Ref & Maize & Abbrev & Ref \\
\hline $\mathrm{RY}=0.99-0.0111 \times \mathrm{AOT} 40$ & AOT40_1 & 32 & $\mathrm{RY}=1.02-0.0036 \times \mathrm{AOT} 40$ & AOT40_5 & 18 \\
\hline $\mathrm{RY}=0.99-0.0161 \times \mathrm{AOT} 40$ & AOT40_2 & 18 & $\mathrm{RY}=1.03-0.0067 \times \mathrm{AOT} 40$ & AOT40_6 & 36 \\
\hline $\mathrm{RY}=0.99-0.0228 \times \mathrm{AOT} 40$ & AOT40_3 & 33 & $\mathrm{RY}=\exp \left[-(\mathrm{M} 7 / 158.0)^{3.69}\right] / \exp \left[-(25.0 / 158.0)^{3.69}\right]$ & M7_2 & 17 \\
\hline $\mathrm{RY}=\exp (-0.0255 \times \mathrm{AOT} 40)$ & AOT40_4 & 33 & $\mathrm{RY}=\exp \left[-(\mathrm{M} 12 / 124)^{2.83}\right] / \exp \left[-(20.0 / 124)^{2.83}\right]$ & M12 & 14 \\
\hline $\mathrm{RY}=\exp \left[-(\mathrm{M} 7 / 137)^{2.34}\right] / \exp \left[-(25 . / 137)^{2.34}\right]$ & M7_1 & 17 & $\mathrm{RY}=\exp \left[-(\mathrm{W} 126 / 93.7)^{3.392}\right]$ & W126_3 & 31 \\
\hline $\mathrm{RY}=1.00-0.017 \times \mathrm{SUM} 06$ & SUM06_1 & 34 & & & \\
\hline $\mathrm{RY}=\exp \left[-(\mathrm{SUM} 06 / 52.32)^{2.176}\right]$ & SUM06_2 & 31 & RYL is calculated as below: & & \\
\hline $\mathrm{RY}=\exp \left[-(\mathrm{W} 126 / 51.2)^{1.747}\right]$ & W126_1 & 15 & $\mathrm{RYL}=1-\mathrm{RY}$ & & \\
\hline $\mathrm{RY}=\exp \left[-(\mathrm{W} 126 / 53.4)^{2.367}\right]$ & W126_2 & 35 & & & \\
\hline
\end{tabular}


253 The improved WRF-Chem model version 3.7.1 was used in this study, and the adopted physical and 254 chemical schemes are shown in Table S8. Two domains were used. Domain one covers East Asia with 255 a horizontal resolution of $81 \mathrm{~km}$ and contains $82 \times 64$ grid cells, and domain two covers NCP and its 256 surrounding area with a horizontal resolution of $27 \mathrm{~km}$, containing $45 \times 45$ grid cells (Fig. 6). 257 Anthropogenic emissions for whole East Asia were taken from the MIX emission inventory 258 (http://www.meicmodel.org/) for $2010^{37}$. The MIX inventory included both gaseous and aerosol 259 species, i.e., $\mathrm{SO}_{2}, \mathrm{NO}_{x}, \mathrm{CO}$, VOCs, $\mathrm{NH}_{3}, \mathrm{PM}_{10}, \mathrm{PM}_{2.5}, \mathrm{BC}, \mathrm{OC}$ and $\mathrm{CO}_{2}$, and was provided monthly by five sectors (power, industry, residential, transportation and agriculture) at a resolution of $0.25^{\circ} \times$ $0.25^{\circ}$. VOCs emissions were speciated into model-ready inputs according to the MOZART chemical mechanism to build the WRF-Chem emission files. In this study, anthropogenic emissions in China in 2016 were replaced by employing the MEIC (Multi-resolution Emission Inventory for China) developed by Tsinghua University. The $\mathrm{NH}_{3}$ emissions in China were from Dong et al. ${ }^{38}$, biomass burning emissions were from Huang et al. ${ }^{39}$ and biogenic emissions were calculated using the Model of Emissions of Gases and Aerosols from Nature (MEGAN) ${ }^{40}$. The $1^{\circ} \times 1^{\circ}$ final reanalysis data (FNL) 41 from the National Centers for Environmental Prediction (NCEP) were used in this study to obtain the meteorological initial and boundary conditions (every $6 \mathrm{~h}$ ). The global simulations of MOZART-4 (https://www.acom.ucar.edu/wrf-chem/mozart.shtml) were used as the chemical initial and boundary conditions (every $6 \mathrm{~h}$ ) for this study. 


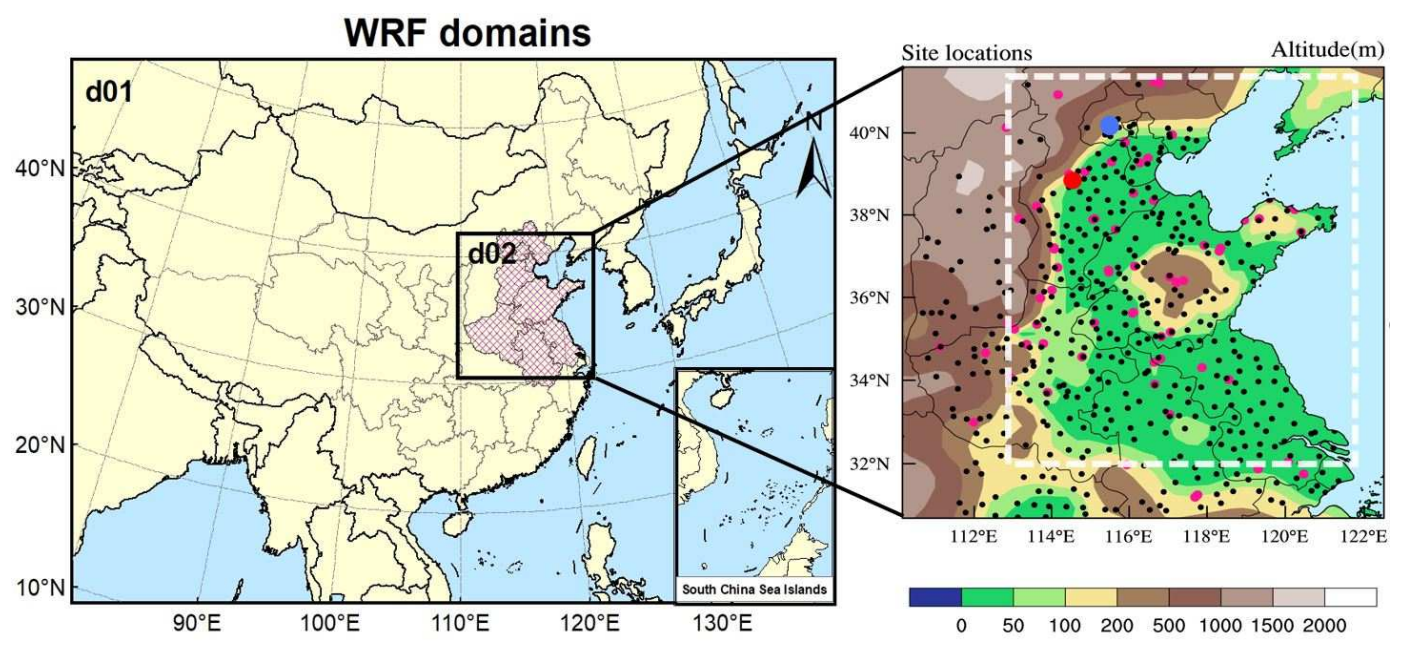

272 Fig. 6 Domains of the WRF-Chem model (left panel), and the locations of the HONO observation sites (the red dot

273 is the rural site in the cropland of Wangdu, and the navy-blue dot is the urban site in Beijing), $\mathrm{NO}_{2}$ and $\mathrm{O}_{3}$ observation 274 sites (69 deep pink dots), and meteorological observation sites (410 black dots) in domain 2 (right panel). The white 275 rectangle in the right panel represents the core region of the North China Plain (NCP) we concerned.

According to the actual wheat-maize rotation system in NCP in 2016, the growing seasons affected by $\mathrm{O}_{3}$ were defined as the period from March 01 to May 31 (92 days) for wheat and from July 01 to September 30 (92 days) for maize. Two simulation cases (Base and 6S, Table S9) were conducted for each of the 6 months. Other 15 additional cases (Table S9) were performed to discuss the uncertainty of VOC emissions in the $\mathrm{O}_{3}$ simulations (cases base_115VOCs and 6S_115VOCs), the uncertainty of $\mathrm{NO}_{\mathrm{x}}$ emissions in the $\mathrm{O}_{3}$ simulations (cases base_85NOx and 6S_85NOx), the relative contribution of each HONO source to the HONO simulations (cases A, B, C, D, E and Nit_30), and the uncertainty of $\alpha$ and $\mathrm{J}_{\text {nitrate }} / \mathrm{J}_{\mathrm{HNO}}$ ratios in the HONO simulations (cases 6S_100, $6 \mathrm{~S} \_200 \alpha$, Nit_1, Nit_7, Nit_30 and

Nit_120). All the simulation cases were conducted with a spin-up period of 7 days.

\section{Potential HONO sources considered in this study}

The base case only considered the key homogeneous formation of $\mathrm{HONO}(\mathrm{NO}+\mathrm{OH} \rightarrow \mathrm{HONO}$ ), 
whereas case $6 \mathrm{~S}$ contained six potential HONO sources, i.e., traffic emissions ${ }^{42}$, soil emissions ${ }^{43}$, indoor emissions ${ }^{7}$, inorganic nitrate photolysis in the atmosphere (R9) ${ }^{44}$, and nitrogen dioxide $\left(\mathrm{NO}_{2}\right)$ heterogeneous reactions on aerosol and ground surfaces ${ }^{45}$.

$$
p \mathrm{NO}_{3}+h v \rightarrow 0.67 \mathrm{HONO}+0.33 \mathrm{NO}_{2}
$$

The traffic emission was calculated by a $\mathrm{HONO} / \mathrm{NO}_{\mathrm{x}}$ ratio of $0.8 \%{ }^{42}$; the soil emissions were chosen with low emission fluxes ${ }^{7,8,43}$ and the reason for this choice is provided in Zhang et al. ${ }^{7}$. The indoor emission source had a small influence only in urban areas with an emission rate of $2.36 \mathrm{ngNm}^{-2} \mathrm{~s}^{-1} 40$. Nitrate photolysis was computed by a $\mathbf{J}_{\text {nitrate }} / \mathbf{J}_{\mathrm{HNO} 3}$ ratio of $30^{9,25}$ (ratios of 1,7 and 120 were conducted for the uncertainty analysis), where $\mathrm{J}_{\text {nitrate }}$ and $\mathrm{J}_{\mathrm{HNO}}$ denote the photolysis frequency of nitrate and gas nitric acid, respectively. The $\mathrm{NO}_{2}$ heterogeneous reactions were parameterized according to the work of $\mathrm{Li}$ et al. ${ }^{4}$ and Liu et al. ${ }^{46}$, and both studies considered the photo-enhanced processes on the previous work ${ }^{4,7,46}$ and calculated by (E6) and (E7), where SR denotes solar radiation (W m $\left.{ }^{-2}\right), \alpha$ is an adjusted factor set as $300 \mathrm{~W} \mathrm{~m}^{-2}\left(\alpha=100\right.$ or $200 \mathrm{~W} \mathrm{~m}^{-2}$ for the uncertainty analysis), and $\gamma$ and $f$ become continuous functions during the whole day. Assuming that the intensity of SR reached $900 \mathrm{~W}$ $\mathrm{m}^{-2}$ around noon, the maximum values of $\gamma$ and $f$ reached $2.0 \times 10^{-5}$ and 0.40 , respectively, which are comparable with previous studies ${ }^{46,50}$. ground/aerosol surfaces ${ }^{47-49}$. In this study, the uptake coefficient $(\gamma)$ of $\mathrm{NO}_{2}$ on aerosol and ground surfaces, and the yield $(f)$ of $\mathrm{HONO}$ from $\mathrm{NO}_{2}$ reaching the ground surface $(f \leq 1)$ were improved from 
Two field measurements of HONO were collected in the summer of 2016, including a rural site and an urban site. The rural site was in an agricultural field in Wangdu County $\left(38.70^{\circ} \mathrm{N}, 115.25^{\circ} \mathrm{E}\right)$, which is a typical site surrounded by agricultural fields with a winter wheat-summer maize rotation in NCP 51. A stripping coil-ion chromatograph (SC-IC) method was used for the HONO measurement from July 09 to August 12, with a time resolution of $1 \mathrm{~h}$ and a detection limit of $20 \mathrm{ppt}^{52}$. The urban site was at the campus of Beijing Normal University $\left(39.96^{\circ} \mathrm{N}, 116.36^{\circ} \mathrm{E}\right)$, using the long-path liquid absorption photometer (LOPAP) ${ }^{53}$ with a time resolution of $1 \mathrm{~h}$ and a detection limit of 20 ppt. Ground

$\mathrm{O}_{3}$ and $\mathrm{NO}_{2}$ mixing ratios were obtained from https://quotsoft.net/air/, issued by the China Ministry of Ecology and Environment; nitrate observations were absent during the study period; and surface meteorological observations were obtained from the National Climatic Data Center, China Meteorological Administration ${ }^{54}$. A total of $69 \mathrm{O}_{3} / \mathrm{NO}_{2}$ observation sites and 410 meteorological observation sites were used, and their locations are shown in the right panel of Fig. 6.

\section{Definition of statistical measures}

The statistical measures used in this study including the mean bias (MB), normalized mean bias

(NMB), root mean square error (RMSE) and index of agreement (IOA). The MB, NMB, RMSE and

IOA are calculated as follow:

Mean Bias $(\mathrm{MB})=\frac{\sum_{i=1}^{N}\left(P_{i}-O_{i}\right)}{N}$

Normalized Mean Bias $(\mathrm{NMB})=\frac{\sum_{i=1}^{N}\left(P_{i}-O_{i}\right)}{\sum_{i=1}^{N} O_{i}} \times 100 \%$

Root Mean Square Error $(\mathrm{RMSE})=\sqrt{\frac{\sum_{i=1}^{N}\left(P_{i}-O_{i}\right)^{2}}{(N-1)}}$

328 
Where $P_{i}$ represents the simulated data and $O_{i}$ represents the observed data. $N$ means the number of data pairs. $\bar{O}$ is the mean of observations.

\section{Model performance for meteorological factors and $\mathrm{NO}_{2}$}

The statistical values of the 410-site-averaged simulations of air temperature, relative humidity and wind speed were comparable with those of previous studies (Table S10), and the wind direction biases within $45^{\circ}$ were over 50\% in both seasons (Table S10). Overall, the simulations of the meteorological variables are reasonable.

The 69-site-averaged hourly and diurnal variations of $\mathrm{NO}_{2}$ in the two growing seasons were well simulated (Fig. S13\&S14). The mean $\mathrm{NO}_{2}$ for the base and $6 \mathrm{~S}$ cases and the observations in the wheat/maize growing seasons were $21.76 / 20.76,20.77 / 19.71$ and $21.40 / 17.43 \mathrm{ppb}$, respectively. The nighttime $\mathrm{NO}_{2}$ for the $6 \mathrm{~S}$ case was closer to the observations compared with the base case after considering the heterogeneous consumption of $\mathrm{NO}_{2}$ leading to $\mathrm{HONO}$ formation (Fig. S14). Nighttime $\mathrm{NO}_{2}$ overestimation could be related mainly to the uncertainty in the $\mathrm{NO}_{\mathrm{x}}$ emissions (Fig. S13\&S14), which probably caused the overestimation of nighttime HONO by $\sim 0.2-0.5 \mathrm{ppb}$ at both sites (Fig .1).

Calculation of $R Y L_{b a s e}, R Y L_{6 S}$ and $R Y L_{O b s}$

$$
R Y L_{6 S}=1-R Y_{6 S}
$$

$$
R Y L_{O b s}=1-R Y_{O b s}
$$


where $\mathrm{RY}_{\text {base }}, \mathrm{RY}_{6 \mathrm{~S}}$ and $\mathrm{RY}_{\mathrm{Obs}}$ are calculated by applying the simulated (base and $6 \mathrm{~S}$ cases) and the

observed $\mathrm{O}_{3}$ mixing ratios, respectively, into the ER equations. The relative contribution in the lower

panel of Fig. 4 is defined as below:

Relative contribution $=\frac{\left(R Y L_{6 S}-R Y L_{\text {base }}\right)}{R Y L_{O b s}} \times 100 \%$

\section{Competing interests}

The authors declare no competing interests.

\section{References}

Alicke, B., Platt, U. \& Stutz, J. Impact of nitrous acid photolysis on the total hydroxyl radical budget during the Limitation of Oxidant Production/Pianura Padana Produzione di Ozono study in Milan. J Geophys Res-Atmos 107, doi:10.1029/2000jd000075 (2002).

Hendrick, F. et al. Four years of ground-based MAX-DOAS observations of $\mathrm{HONO}$ and $\mathrm{NO}_{2}$ in the Beijing area. Atmospheric Chemistry and Physics 14, 765-781, doi:10.5194/acp-14-765-2014 (2014).

Kim, S. et al. The primary and recycling sources of OH during the NACHTT-2011 campaign: HONO as an important $\mathrm{OH}$ primary source in the wintertime. $J$ Geophys Res-Atmos 119, 6886-6896, doi:10.1002/2013jd019784 (2014). Campaign. Atmospheric Chemistry and Physics 10, 6551-6567, doi:10.5194/acp-10-6551-2010 (2010). Atmospheric Environment 45, 4735-4744, doi:10.1016/j.atmosenv.2011.04.086 (2011). Sarwar, G. et al. A comparison of CMAQ HONO predictions with observations from the northeast oxidant and particle study. Atmospheric Environment 42, 5760-5770, doi:10.1016/j.atmosenv.2007.12.065 (2008).

Zhang, J., An, J., Qu, Y., Liu, X. \& Chen, Y. Impacts of potential HONO sources on the concentrations of oxidants and secondary organic aerosols in the Beijing-Tianjin-Hebei region of China. The Science of the total environment 647, 836-852, doi:10.1016/j.scitotenv.2018.08.030 (2019). Zhang, L. et al. Potential sources of nitrous acid (HONO) and their impacts on ozone: A WRF-Chem study in a polluted subtropical region. J Geophys Res-Atmos 121, 3645-3662, doi:10.1002/2015jd024468 (2016). $\mathrm{Fu}$, X. et al. The significant contribution of HONO to secondary pollutants during a severe winter pollution event in southern China. Atmospheric Chemistry and Physics 19, 1-14, doi:10.5194/acp-19-1-2019 (2019).

Mills, G. et al. Ozone pollution will compromise efforts to increase global wheat production. Glob Chang Biol 24, 3560-3574, doi:10.1111/gcb.14157 (2018).

11 Richards, B. L., Middleton, J. T. \& Hewitt, W. B. Air Pollution With Relation to Agronomic Crops: V. Oxidant Stipple of Grape. Agronomy Journal 50, 559-561 (1958).

12 Wilkinson, S., Mills, G., Illidge, R. \& Davies, W. J. How is ozone pollution reducing our food supply? J Exp Bot 
63, 527-536, doi:10.1093/jxb/err317 (2012).

13 Ainsworth, E. A. Understanding and improving global crop response to ozone pollution. Plant J 90, 886-897, doi:10.1111/tpj.13298 (2017).

14 Heck, W. W. et al. Assessment of Crop Loss from Ozone. Journal of the Air Pollution Control Association 32, 353-361, doi:10.1080/00022470.1982.10465408 (1982).

15 Allen, S., Lefohn, , John, A. L. \& Kohut, R. J. A comparison of indices that describe the relationship between exposure to ozone and reduction in the yield of agricultural crops Atmospheric Environment 22, 1229-1240 (1988).

16 Fuhrer, J., Skarby, L. \& Ashmore, M. R. Critical levels for ozone effects on vegetation in Europe. Environ Pollut 97, 91-106, doi:10.1016/s0269-7491(97)00067-5 (1997).

17 Lesser, V. M., Rawlings, J. O., Spruill, S. E. \& Somerville, M. C. Ozone Effects on Agricultural Crops: Statistical Methodologies and Estimated Dose-Response Relationships. Crop Science 30, 148-155, doi:10.2135/cropsci1990.0011183X003000010033x (1990).

18 Mills, G. et al. A synthesis of AOT40-based response functions and critical levels of ozone for agricultural and horticultural crops. Atmospheric Environment 41, 2630-2643, doi:10.1016/j.atmosenv.2006.11.016 (2007). Avnery, S., Mauzerall, D. L., Liu, J. \& Horowitz, L. W. Global crop yield reductions due to surface ozone exposure: 2. Year 2030 potential crop production losses and economic damage under two scenarios of $\mathrm{O}_{3}$ pollution. Atmospheric Environment 45, 2297-2309, doi:10.1016/j.atmosenv.2011.01.002 (2011).

20 Feng, Z., Hu, T., Tai, A. P. K. \& Calatayud, V. Yield and economic losses in maize caused by ambient ozone in the North China Plain (2014-2017). The Science of the total environment 722, 137958, doi:10.1016/j.scitotenv.2020.137958 (2020).

21 Zhao, H., Zheng, Y., Zhang, Y. \& Li, T. Evaluating the effects of surface $\mathrm{O}_{3}$ on three main food crops across China during 2015-2018. Environ Pollut 258, 113794, doi:10.1016/j.envpol.2019.113794 (2020).

22 Li, K. et al. Anthropogenic drivers of 2013-2017 trends in summer surface ozone in China. Proceedings of the National Academy of Sciences of the United States of America 116, 422-427, doi:10.1073/pnas.1812168116 (2019).

23 Ma, Z. Q. et al. Significant increase of surface ozone at a rural site, north of eastern China. Atmospheric Chemistry and Physics 16, 3969-3977, doi:DOI 10.5194/acp-16-3969-2016 (2016).

24 Zhu, X. K. et al. Effects of elevated ozone concentration on yield of four Chinese cultivars of winter wheat under fully open-air field conditions. Glob. Change Biol. 17, 2697-2706, doi:10.1111/j.1365-2486.2011.02400.x (2011).

25 Romer, P. S. et al. Constraints on Aerosol Nitrate Photolysis as a Potential Source of HONO and NOx. Environmental science \& technology 52, 13738-13746, doi:10.1021/acs.est.8b03861 (2018).

26 Shi, Q. et al. Laboratory Investigation of Renoxification from the Photolysis of Inorganic Particulate Nitrate. Environmental science \& technology, doi:10.1021/acs.est.0c06049 (2021).

27 Ye, C., Gao, H., Zhang, N. \& Zhou, X. Photolysis of Nitric Acid and Nitrate on Natural and Artificial Surfaces. Environmental science \& technology 50, 3530-3536, doi:10.1021/acs.est.5b05032 (2016).

28 Xue, C., Ye, C., Zhang, C., Catoire, V. \& Mu, Y. Evidence for Strong HONO Emission from Fertilized Agricultural Fields and its Remarkable Impact on Regional O 3 Pollution in the Summer North China Plain. ACS Earth Space Chem. (2021).

29 Elshorbany, Y. F., Steil, B., Bruhl, C. \& Lelieveld, J. Impact of HONO on global atmospheric chemistry calculated with an empirical parameterization in the EMAC model. Atmospheric Chemistry and Physics 12, 9977-10000, doi:10.5194/acp-12-9977-2012 (2012).

30 Gligorovski, S., Strekowski, R., Barbati, S. \& Vione, D. Environmental Implications of Hydroxyl Radicals (*OH). Chem Rev 115, 13051-13092, doi:10.1021/cr500310b (2015).

31 Wang, X. P. \& Mauzerall, D. L. Characterizing distributions of surface ozone and its impact on grain production 
in China, Japan and South Korea: 1990 and 2020. Atmospheric Environment 38, 4383-4402, doi:10.1016/j.atmosenv.2004.03.067 (2004). Zhao, H. et al. Long term variations of ozone concentration of in a winter wheat field and its loss estimate based on dry matter and yield. Environmental Science (Chinese) 38, 5315-5325, doi:10.13227/j.hjkx.201704117 (2017).

33 Wang, $\mathrm{X}$. et al. Effects of elevated $\mathrm{O}_{3}$ concentration on winter wheat and rice yields in the Yangtze River Delta, China. Environ. Pollut. 171, 118-125, doi:10.1016/j.envpol.2012.07.028 (2012).

Tong, L. et al. Stomatal ozone uptake modeling and comparative analysis of flux-response relationships of winter wheat. Acta Ecologica Sinica 032, 2890-2899 (2012). Lapina, K., Henze, D. K., Milford, J. B. \& Travis, K. Impacts of Foreign, Domestic, and State-Level Emissions on Ozone-Induced Vegetation Loss in the United States. Environmental science \& technology 50, 806-813, doi:10.1021/acs.est.5b04887 (2016).

Singh, A. A., Agrawal, S. B., Shahi, J. P. \& Agrawal, M. Assessment of growth and yield losses in two Zea mays L. cultivars (quality protein maize and nonquality protein maize) under projected levels of ozone. Environ Sci Pollut Res Int 21, 2628-2641, doi:10.1007/s11356-013-2188-6 (2014).

Li, M. et al. MIX: a mosaic Asian anthropogenic emission inventory under the international collaboration framework of the MICS-Asia and HTAP. Atmospheric Chemistry and Physics 17, 935-963, doi:10.5194/acp-17935-2017 (2017).

Dong, W.X., Xing, J. \& Wang, S.X. Temporal and spatial distribution of anthropogenic ammonia emissions in China: 1994-2006. Environmental Sciences (in Chinese) 31, 1457-1463 (2010).

39 Huang, X., Li, M. M., Li, J. F. \& Song, Y. A high-resolution emission inventory of crop burning in fields in China based on MODIS Thermal Anomalies/Fire products. Atmospheric Environment 50, 9-15, doi:10.1016/j.atmosenv.2012.01.017 (2012). extended and updated framework for modeling biogenic emissions. Geoscientific Model Development 5, 14711492, doi:10.5194/gmd-5-1471-2012 (2012).

341, 1233-1235, doi:10.1126/science.1242266 (2013).

44 Zhou, X. et al. Nitric acid photolysis on surfaces in low- $\mathrm{NO}_{\mathrm{x}}$ environments: Significant atmospheric implications. Geophysical Research Letters 30, doi:10.1029/2003g1018620 (2003).

45 Finlayson-Pitts, B. J., Wingen, L. M., Sumner, A. L., Syomin, D. \& Ramazan, K. A. The heterogeneous hydrolysis of $\mathrm{NO}_{2}$ in laboratory systems and in outdoor and indoor atmospheres: An integrated mechanism. Physical Chemistry Chemical Physics 5, 223-242, doi:10.1039/b208564j (2003). (2000). NCEP FNL Operational Model Global Tropospheric Analyses, continuing from July 1999. Boulder: Research Data Archive at the National Center for Atmospheric Research, Computational and Information Systems Laboratory. https://doi.org/10.5065/D6M043C6. Atmospheric Environment 35, 3385-3394, doi:Doi 10.1016/S1352-2310(01)00138-8 (2001).

Liu, Z. et al. Evidence of aerosols as a media for rapid daytime HONO production over China. Environmental science \& technology 48, 14386-14391, doi:10.1021/es504163z (2014).

Monge, M. E. et al. Light changes the atmospheric reactivity of soot. Proceedings of the National Academy of Sciences of the United States of America 107, 6605-6609, doi:10.1073/pnas.0908341107 (2010).

Stemmler, K., Ammann, M., Donders, C., Kleffmann, J. \& George, C. Photosensitized reduction of nitrogen dioxide on humic acid as a source of nitrous acid. Nature 440, 195-198, doi:10.1038/nature04603 (2006). 
47149 Stemmler, K. et al. Light induced conversion of nitrogen dioxide into nitrous acid on submicron humic acid aerosol. Atmospheric Chemistry and Physics 7, 4237-4248, doi:DOI 10.5194/acp-7-4237-2007 (2007). Gall, E. T. et al. Evaluation of nitrous acid sources and sinks in urban outflow. Atmospheric Environment 127, 272-282, doi:10.1016/j.atmosenv.2015.12.044 (2016).

Xue, C. et al. Development and application of a twin open-top chambers method to measure soil HONO emission in the North China Plain. The Science of the total environment 659, 621-631, doi:10.1016/j.scitotenv.2018.12.245 (2019).

Xue, C. et al. Development of stripping coil-ion chromatograph method and intercomparison with CEAS and LOPAP to measure atmospheric HONO. The Science of the total environment 646, 187-195, doi:10.1016/j.scitotenv.2018.07.244 (2019). Kleffmann, J., Heland, J., Kurtenbach, R., Lorzer, J. \& Wiesen, P. A new instrument (LOPAP) for the detection of nitrous acid (HONO). Environmental Science and Pollution Research 9, 48-54 (2002).

Wang, F. et al. Impacts of uncertainty in AVOC emissions on the summer ROx budget and ozone production rate in the three most rapidly-developing economic growth regions of China. Advances in Atmospheric Sciences 31, 1331-1342, doi:10.1007/s00376-014-3251-z (2014). 
Figures
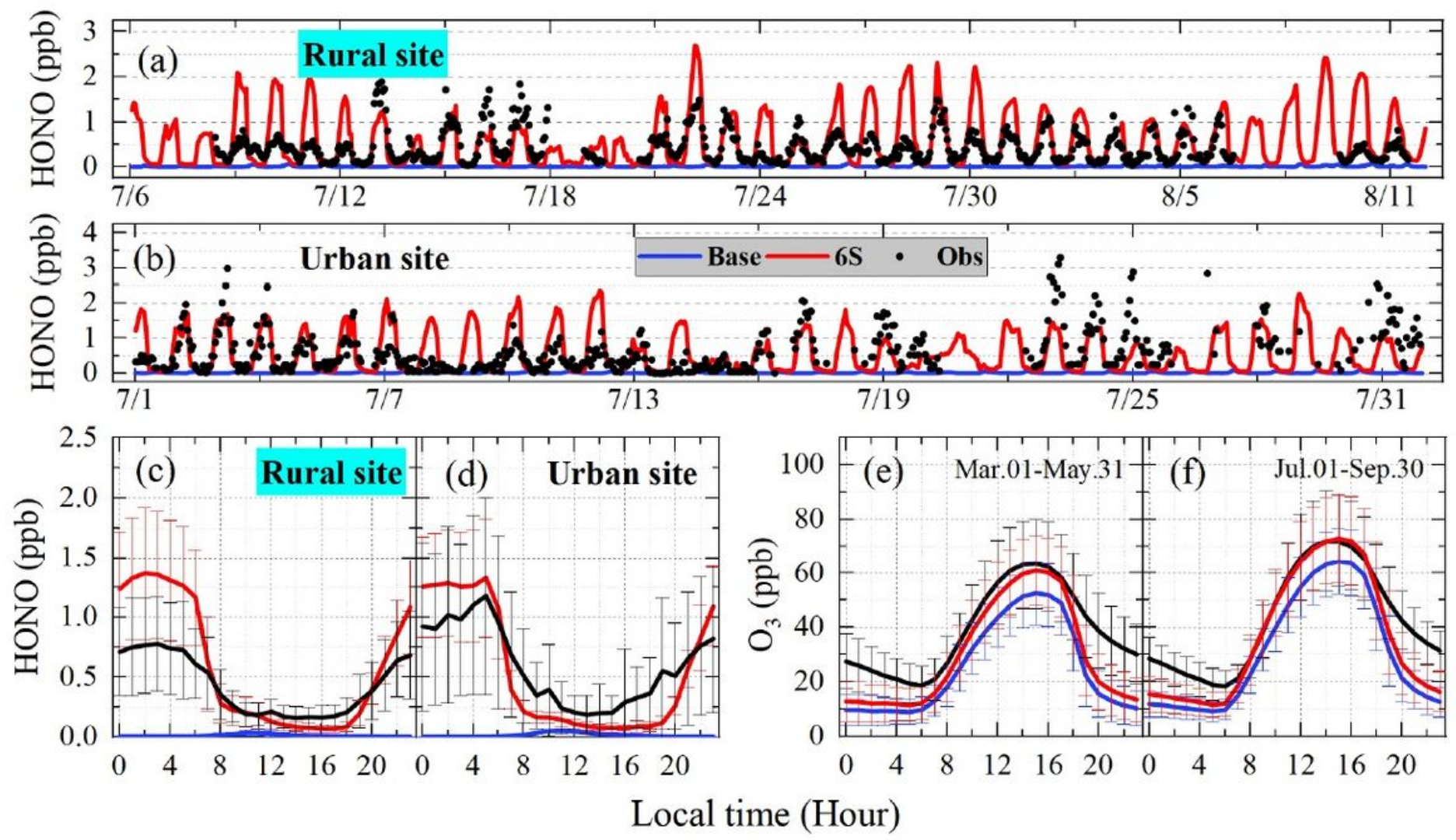

Figure 1

Comparison of simulated (Base and 6S cases) and observed hourly and diurnal HONO mixing ratios at the rural ( $a \& c)$ and urban (b\&d) sites in summer of 2016, and comparison of simulated (Base and 6S cases) and observed 69-site-averaged diurnal 03 in the North China Plain during the wheat (e) and maize (f) growing seasons in 2016. 

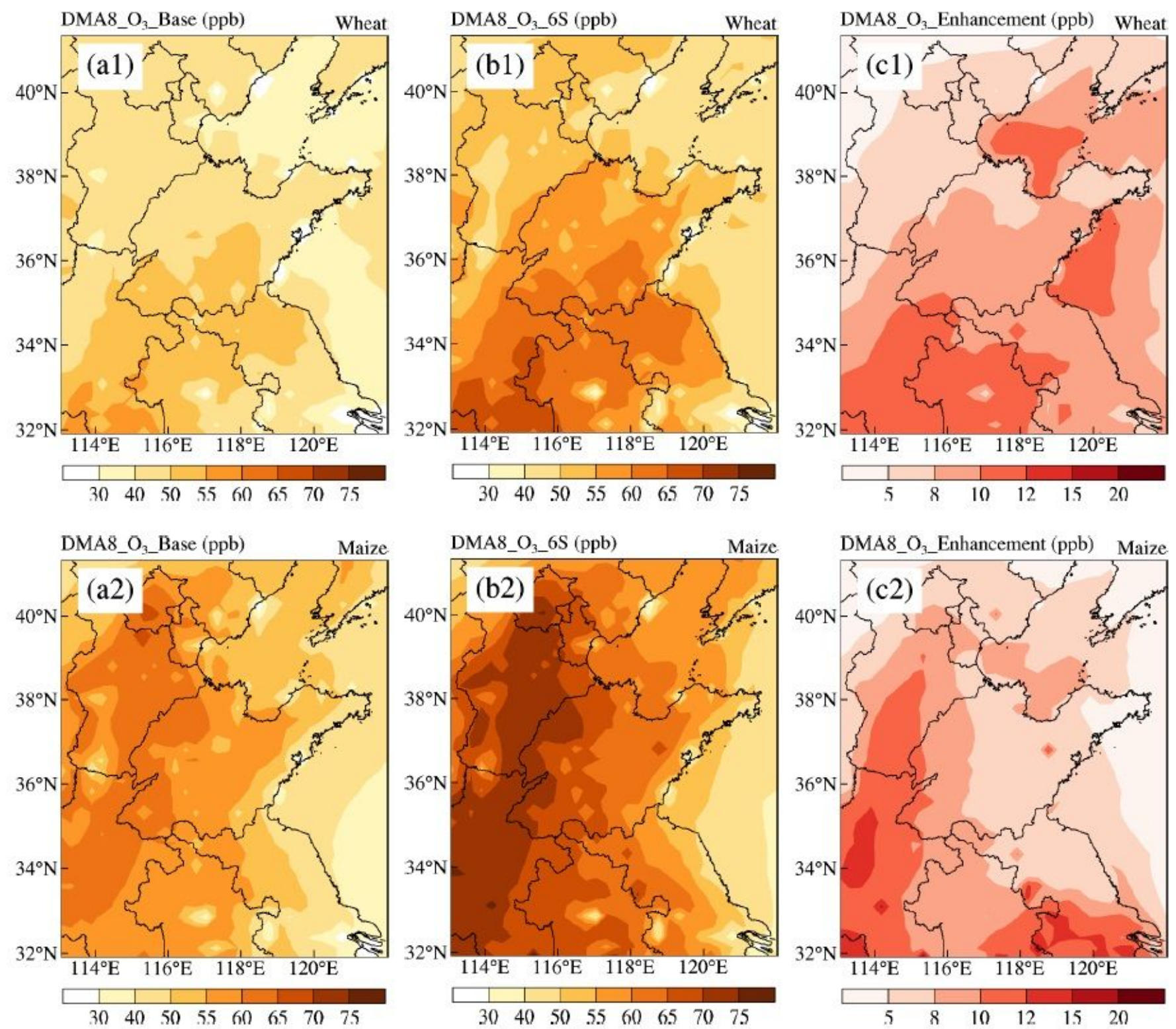

\section{Figure 2}

Daily maximum 8-h (10:00-17:59) surface 03 simulations for the base (a1/a2) and 6S cases (b1/b2) and the enhancements (c1/c2) induced by the potential HONO sources during the wheat/maize growing season. Note: The designations employed and the presentation of the material on this map do not imply the expression of any opinion whatsoever on the part of Research Square concerning the legal status of any country, territory, city or area or of its authorities, or concerning the delimitation of its frontiers or boundaries. This map has been provided by the authors. 


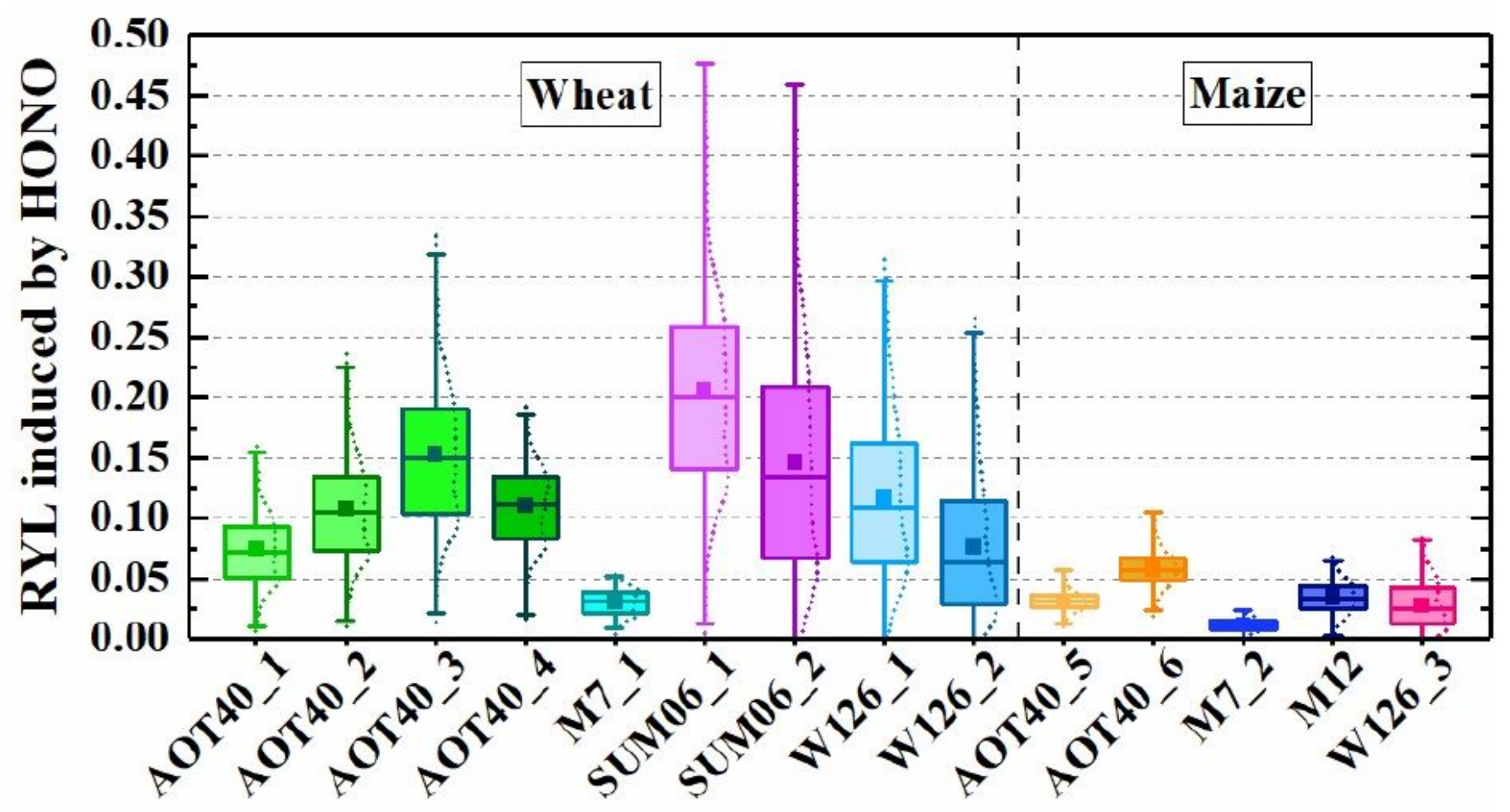

Figure 3

Box plots of the relative yield loss (RYL) induced by the potential HONO sources calculated by the 14 exposure-response (ER) equations in NCP in 2016. 


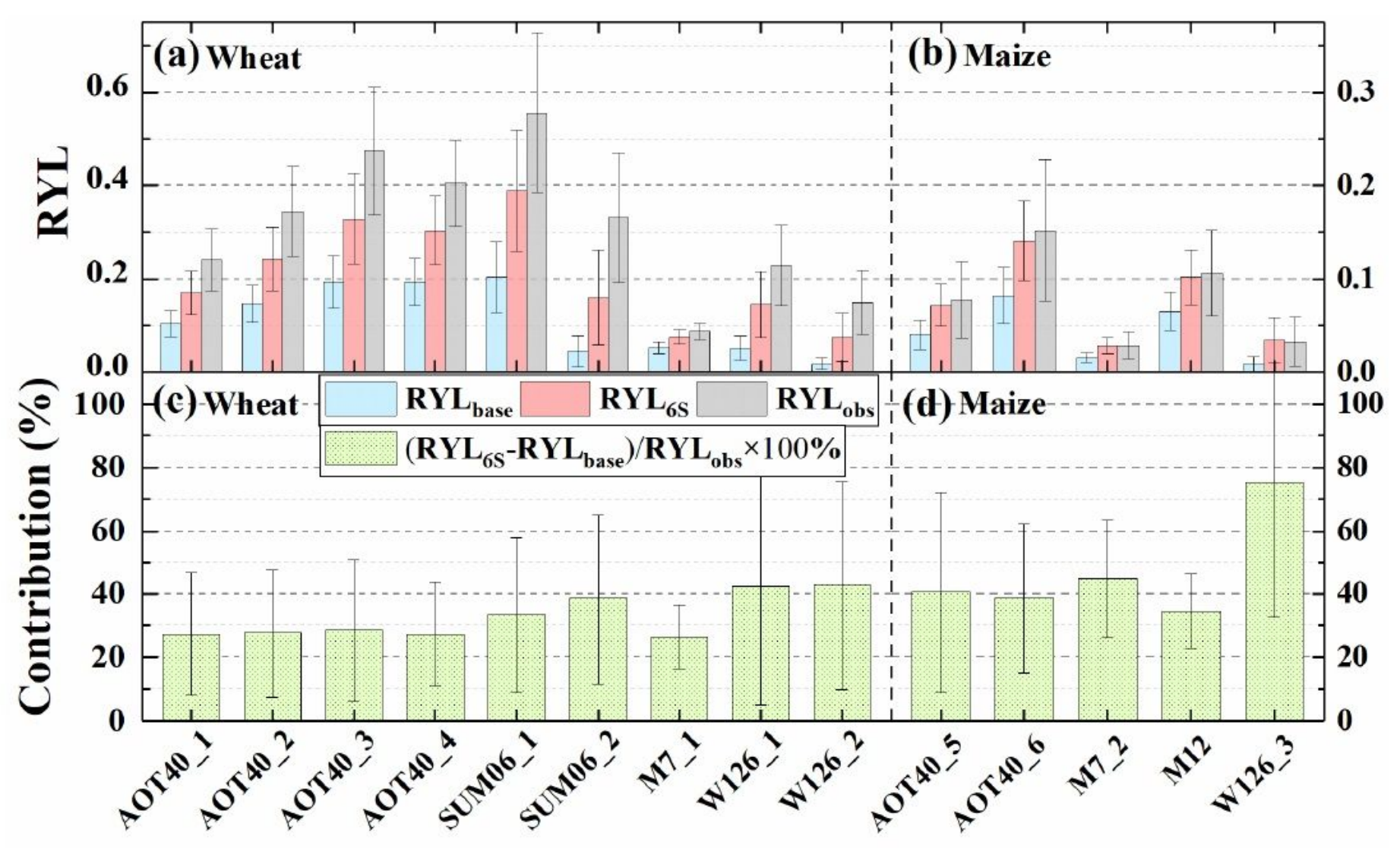

Figure 4

The 69-site-averaged relative yield loss (RYL) values calculated by using 14 Exposure-Response (ER) equations for the base (RYLbase, light blue histogram) and 6S (RYL6S, light red histogram) cases and observed 03 (RYLobs, gray histogram) for wheat (a) and maize (b); and the relative contribution of the RYL caused by the enhanced 03 (03 simulations of the $6 \mathrm{~S}$ case minus those of the base case) to the actual RYL (RYLobs) for wheat (c) and maize (d). 


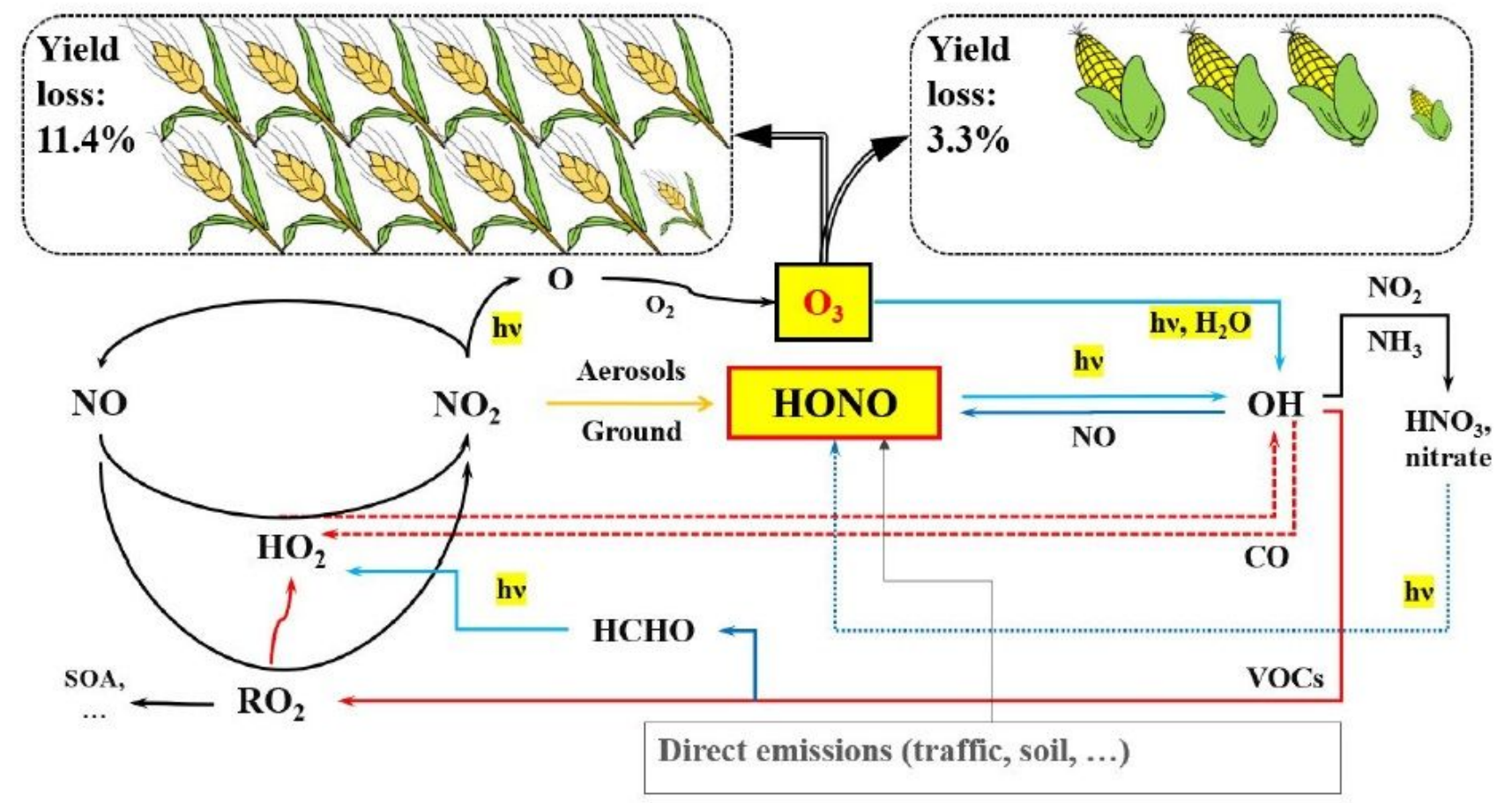

Figure 5

The key mechanism of ozone (03) formation induced by nitrous acid (HONO) and the relative yield losses induced by potential HONO sources in North China Plain in 2016 for wheat and maize.

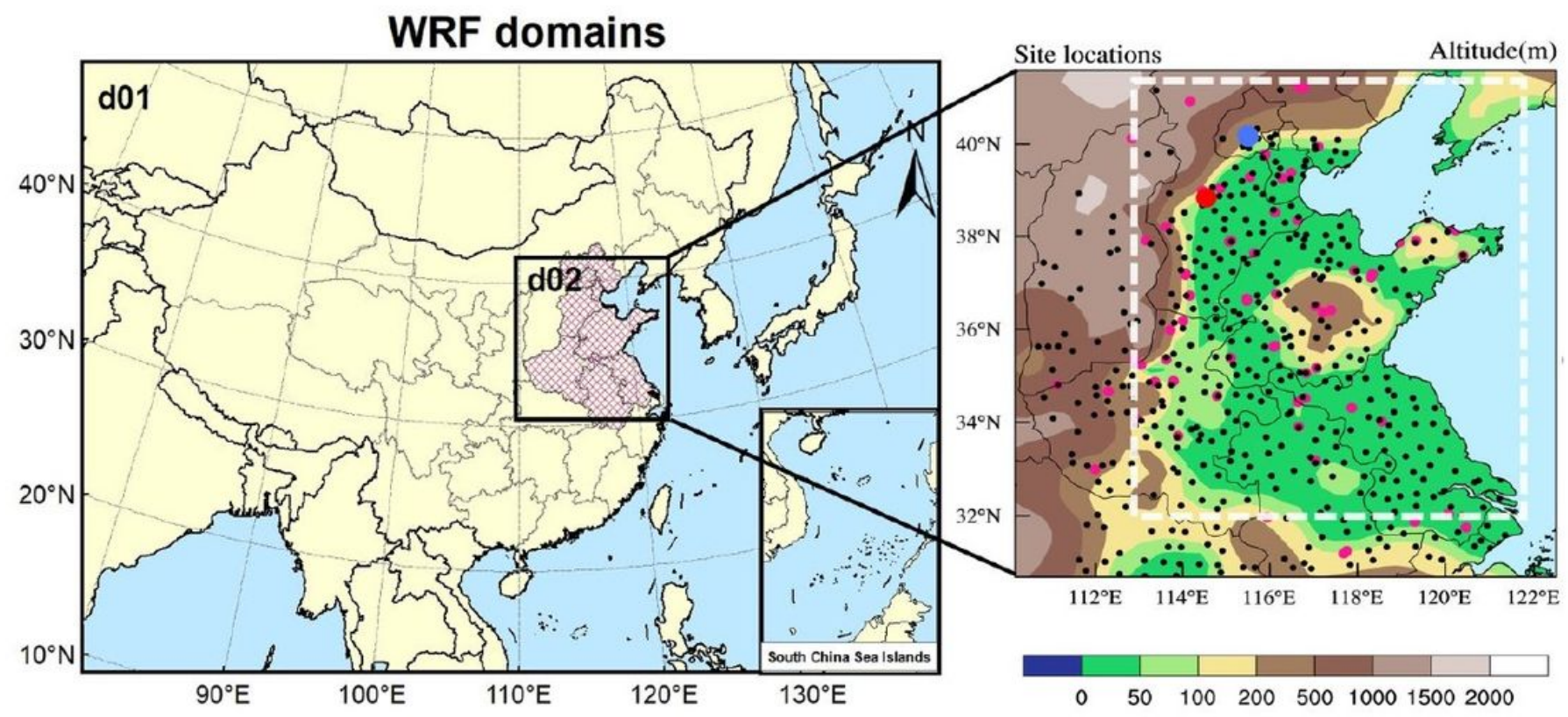

Figure 6 
Domains of the WRF-Chem model (left panel), and the locations of the HONO observation sites (the red dot is the rural site in the cropland of Wangdu, and the navy-blue dot is the urban site in Beijing), NO2 and 03 observation sites (69 deep pink dots), and meteorological observation sites (410 black dots) in domain 2 (right panel). The white rectangle in the right panel represents the core region of the North China Plain (NCP) we concerned. Note: The designations employed and the presentation of the material on this map do not imply the expression of any opinion whatsoever on the part of Research Square concerning the legal status of any country, territory, city or area or of its authorities, or concerning the delimitation of its frontiers or boundaries. This map has been provided by the authors.

\section{Supplementary Files}

This is a list of supplementary files associated with this preprint. Click to download.

- NaturefoodSI.docx 